\begin{tabular}{|c|c|c|c|}
\hline Article Info & RESEARCH ARTICLE & ARAŞTIRMA MAKALESİ & \\
\hline Title of Article & \multicolumn{2}{|c|}{$\begin{array}{l}\text { Metropolitan Turbulence: } \\
\text { Local Elections and the Sociological } \\
\text { Dynamics on the Background of the } \\
\text { Conservative Political Policy }\end{array}$} & 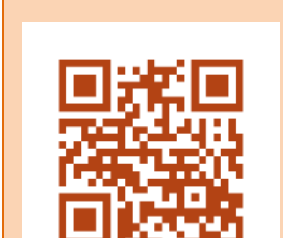 \\
\hline $\begin{array}{l}\text { Corresponding } \\
\text { Author }\end{array}$ & \multicolumn{2}{|c|}{$\begin{array}{l}\text { İran ÖZET } \\
\text { Aksaray Üniversitesi, Fen-Edebiyat Fakültesi, Sosyoloji Bölümü, } \\
\text { vizyon24@ hotmail.com }\end{array}$} & \\
\hline $\begin{array}{l}\text { Received Date } \\
\text { Accepted Date }\end{array}$ & \multicolumn{2}{|l|}{$07.05 .2020 \quad / / \quad 13.07 .2020$} & \\
\hline Author / Authors & İrfan ÖZET & ORCID: /0000-0003-4612-2305 & \\
\hline How to Cite & \multicolumn{2}{|c|}{$\begin{array}{l}\text { ÖZET I, (2020). Metropolitan Turbulence: Local Elections and the Sociological } \\
\text { Dynamics on the Background of the Conservative Political Policy, Kent Akademisi, } \\
\text { Volume, 13, Issue } 2 \text { Pages, 338-354. }\end{array}$} & $\begin{array}{l}\text { Kent Akademisi } \\
\text { Urban Academy }\end{array}$ \\
\hline
\end{tabular}

\title{
Metropoliten Türbülans: Yerel Seçimler ve Tıkanan Muhafazakâr Siyasetin Arka Planındaki Sosyolojik Dinamikler
}

İran Özet ${ }^{1}$

\begin{abstract}
:
This research focuses on the picture reflected in the metropolitan environments regarding the political power in the 2019 local elections. The success of the opposition bloc in the metropolitan areas rests on a wide social mobility that includes a significant part of the conservative base. The reflection of the emerging protest discourse in the conservative mass is a rational tendency triggered by urbanization, individualization, and rising middle class etc. Increasing rationality evaluates political performance, beyond the identity-centered polarization, based on the future possibilities promised by the social and economic picture. On the other hand, the fault line triggered by the economic-political dynamics is a conduit that integrates many different identity lines of the metropolises. In this context, the "urban nationalism" reflex, due to the growing dissatisfaction with the immigrant / refugee masses becoming part of daily life, comes to the fore. Similar reflexes are gaining momentum with the spread of patronage relations in the public and the disappearance of the institutionalization tradition. Finally, an educated-
\end{abstract}

\footnotetext{
${ }^{1}$ Aksaray University, Sociology Department, Dr. Faculty Member. vizyon24@hotmail.com
} 
precariat mass is added to the opposition circles, which is increasingly growing in metropolitan areas due to the employment instability.

\section{Keywords:}

Local elections, AK Party, Precari

\section{ÖZ}

$\mathrm{Bu}$ araştırma, 2019 yerel seçimlerinde metropol ortamlarına yansıyan tablonun siyasal iktidara dönük boyutlarına odaklanır. Muhalif bloğun metropollerde elde ettiği başarı, muhafazakar tabanın da anlamlı bir parçasını oluşturduğu geniş bir toplumsal hareketliliğe yaslanmakta. Ortaya konan itiraz dilinin muhafazakâr kitledeki tezahürleri orta sınıflaşma, kentleşme, bireyselleşme $\mathrm{vb}$. dinamiklerin tetiklediği rasyonel eğilimlerdir. Artan rasyonalite, siyasal performansı kimlik merkezli kutuplaşma cereyanının ötesinde, sosyal ve ekonomik tablonun vadettiği gelecek ihtimallerinden hareketle değerlendirir. Diğer taraftan ekonomi-politik dinamiklerin tetiklediği fay hattı, metropollerin çok farklı kimlik hatlarını da bütünleştiren bir referans halinde. Bu kapsamda ilk olarak, göçmen/mülteci kitlelerin gündelik yaşamın parçası haline gelişi karşısında duyulan hoşnutsuzluğun adresi halindeki "şehirli milliyetçilik" refleksi öne çıkar. Benzer refleks, kamuda patronaj ilişkilerinin yaygınlaşması ve kurumsallaşma geleneğinin ortadan kalkmasıyla da ivme kazanmakta. Son olarak muhalif halkaya, istihdam alanlarının güvencesizleşmesi ve istikrarsızlaşmasıyla metropollerde giderek kabaran eğitimliprekaryan kitle de eklemlenmekte.

ANAHTAR KELIMELER: Yerel seçimler, Milli Görüş, AK Parti, Prekarya.

\section{GíRIŞ}

Türk siyasetine dair kolektif hafıza, yerel seçimlerin ortaya koyduğu rakamsal tabloya eşlik eden sosyolojik dönüşümlerle yüklü. Özellikle son 30 yıllık bilançoya baktığımızda, siyaset dünyasına dönük hayli trajik ve çarpıcı deneyimlerle karşılaşmaktayız. Sözgelimi 80’ler boyunca tekelci hüviyetteki ANAP siyasetinin tıkanma emareleri, özellikle 89 yerel seçimlerinde net bir şekilde ortaya çıkmaktaydı. Siyasal arenada bir yandan sosyal-demokrasi arayışları merkezileşirken, öte yandan ise ANAP ağırlıklı merkez-sağın politik sarkacı, artık DYP yönüne kaymıştır. Ancak bu tablo siyasal aktörler ve partiler düzeyinde hiyerarşik manzarayı dönüştürse de, Cumhuriyet modernliğinin istikrarlı mecralarına henüz metastas yapacak bir kapasitede değildi. Politik arenada esaslı ve radikal değişimlerin görülmesi adına, sadece beş yıl sonraki 94 yerel seçimlerindeki tablo yetmekteydi. Nitekim Cumhuriyet modernliğinin uzun bir safhasında bir "karş1-hareket" olarak biçimlendirilen siyasal muhafazakârlık, Ankara ve İstanbul gibi dev metropollerde kent iktidarlarına kavuşmaktaydı.

Gerçekten de seçimlerin ortaya koyduğu tablo "yerel” bir skalada yer alsa da, laik seçkinler için bunun "distopik bir gelecek"in habercisi olduğunu anlamak zor olmadı. Ertesi y1ldan itibaren muhafazakâr siyasetin yerelde kazandığı zafere, genel seçimlerdeki birinciliği ve akabinde ulusal 
iktidara kavuştuğu "şok dalgaları" eşlik ediyordu. Laik seçkinlerin bürokrasi, medya ve sermaye kanatlarını paralize eden bu politik depremin tetiklediği fay hatları, günümüz Türkiye'sine uzanacak bir aktif görünüm sergilemekte. Bu anlamda 94 yerel seçimleri, Cumhuriyet modernliğinin rutin akışını teryüz eden önemli bir kavşak.

Benzer olarak, 80 sonrası Türkiyesinin bürokrasi ayağında neredeyse tekelci hüviyete kavuş(turul)muş Fetullahçı grubun tasfiyesine dönük toplumsal konsensüs, ilk olarak 2014 yerel seçimlerinde billurlaşmıştır. Seçim sonuçları, özellikle Türk muhafazakârlığının kendi bünyesinden çıkmış bir oluşumun tasfiyesinden yana ağırlığını koyduğunu simgeliyordu. Nitekim siyaset kurumuna bürokrasi sahasında tasfiyelerle ilgili verilen bu "vize" ile birlikte, "dehşet bilançosu" daha da netleşiyordu: Soğuk savaş döneminin çatışmacı atmosferine uyarlanmış gizli, mesiyanik ve kapalı devre bir network etrafinda bürokrasinin neredeyse tüm bileşenleri kuşatılmıştı. $\mathrm{Bu}$ anlamda modern bürokrasinin işleyiş rutini düşünüldüğünde bir "anomali"yi simgeleyen bu manzaranın değişimine dair toplumsal mutabakat, yerel seçimlerle açığa çıkıyordu.

Diğer taraftan yerel seçimlere yansıyan bu türden çarpıcı tablolar, arka planında hayli geniş ve derinlikli toplumsal süreçlere yaslanarak varlık kazanır. Sözgelimi İslami hareketin 94 seçimlerinde metropollerdeki başarısı, karizmatik aday profillerinin ötesinde, 1950'lerden itibaren kentsel alanlarda hayata geçirdiği bir dizi dayanışmacı ağlarla ilişkilidir. ${ }^{2}$ Aynı zamanda 2014 yerel seçimlerinde, muhafazakâr siyasetin hitap ettiği "habitus"ta sağladığı "rıza üretimi", din-bürokrasi-siyaset üçgeninde 80 sonrasından itibaren birikmiş bir tortunun harekete geçirilmesiyle anlam kazanır. Nitekim Fetullahçı grubun özellikle bürokrasi sahasında neredeyse hiçbir İslami ya da seküler zümrenin varlığına izin vermeyen tekelci örgütlenmesi karşısında tetiklenen "ortak nefret", hayli geniş cephelere uzanıyordu. Bu anlamda "yerellik" sınırlarının ötesine uzanan seçim sonuçları, arkasına yaslandığı bir dizi toplumsal süreçlerden hareketle anlam kazanır.

\section{Araştırmanın Temel Odağı ve Kavramsal Arka Plan}

$\mathrm{Bu}$ araştırma, geçtiğimiz Mart 2019 yerel seçimlerinin muhafazakâr siyasete temas eden yönlerine, arka planındaki bir dizi toplumsal süreçten hareketle odaklanmaktadır. Öncelikli olarak belirtmek gerekir ki muhafazakârlığın kesintisiz siyasal iktidarı, metropol ortamlarında harekete geçirdiği beşeri sermaye ağları ile ilişkilidir. Bu anlamda kentin değişime açık dünyasının bir varyantı olarak, Cumhuriyet tarihinin neredeyse çeyrek asrını kapsayan zaman dilimine damgasını vurmuştur. Kemalist modernliğin giderek statükocu bir karaktere bürünmesi, küresel kapitalizmle entegrasyon iştahı hergeçen gün artan kent piyasa ekonomisi için giderek bir "yük" olarak kodlanıyordu. Bu atmosferde değişim vaadeden bir dünyadan seslenen muhafazakâr siyaset, uzun yıllar kullanabileceği geniş bir hareket alanına kavuşmuştur. Ancak "kentsel rasyonalite"nin hareketli ve kaygan zemini karşısında, güncel muhafazakâr siyaset de "anakronik" bir görüntü çizebilmekte. Daha da ötesinde Türk siyasetine dair kolektif hafıza,

\footnotetext{
${ }^{2}$ İslami hareket, dayanışma ağları ve muhafazakârlık arasındaki bağıntı için bknz İrfan Özet, Fatih-Başakşehir: Muhafazakâr Mahallede İktidar ve Dönüşen Habitus, İletişim Yay., İstanbul, 2019, s. 37-84.
} 
metropollerin başrol oynadığı bu rasyonalite karşısında merkez sağ siyasetin buharlaştığı trajik deneyimleri sürekli hatırlatmakta.

Gelinen noktada 2019 yılında yapılan yerel seçimlerin özellikle metropol alanları etrafında gösterdiği simgesel harita, tıkanan muhafazakar siyasete dair hayli geniş mesajlar içermekte. Yakın tarihteki bir araştırmada vurgulandığı gibi, bu tablonun oluşması öncelikli olarak iktidar bloğu seçmenlerinin partilerinden rahatsız olması ve partilerini sorgulamaya başlamasıyla anlamlandırılmakta. Özellikle İstanbul, Ankara, Adana, Antalya gibi büyükșehirlerde belediye başkanlıklarınının el değiştirmesi, Bursa'da ise oy makasının önemli ölçüde kapanmasında bloklararası oy hareketliğininin etkili olduğu düşünülmektedir (Tosun\&Tosun, 2019: 41). Nitekim Yavuz'un da belirttiği gibi, eleştirel sesleri homojen hale getirme çabalarına rağmen İslami kamusal alanda çok sayıda derin fay hatları vardır. Çekişme ve muhalefet her daim kamusal alanın bir parçasıdır ve yeni Müslüman öznelerin oluşumunun merkezinde bu diyalektik bulunur (Yavuz, 2011: 78).

Bir başka açıdan metropollerin çeyrek asırlık bir siyasal rutini daha doğrusu "konfor"u bozucu eğilimi, muhafazakâr siyasetin yaslandığı taşra merkezli dünyanın kentleşme süreciyle yaşadığı dönüşüm üzerinden okunmakta. Bu çerçevede Çelik'e göre, başlangıç evresinde merkezi fethetmenin bir stratejisi olarak şekillenen taşra İslam'1, merkeze yerleştikçe bir taşra ideolojisi olmaktan çıkar. Merkezileşmeyle eşzamanlı olarak kentlileşen yüzünde, seçkinleştirici kültürel ve kurumsal araçlar öne çıkar. Diğer bir ifadeyle dönüşen taşra, merkezi konformizm ve değerlerle uyumlu bir kimliğe evrilmektedir (Çelik, 2013: 28). Nitekim sosyolojik disiplin, İbn Haldun'un "bedevi-hazeri" çözümlemesine kadar uzanabilecek bir skalada, bu tür evrimleşmelerin kaçınılmaz sosyal gerçekliğine vurgu yapmıştır.

Ancak yaşanan dönüşümü okumakta zorlanan ve siyasal iletişimi taşra-kent, laik-muhafazakâr vb. ayrımların ürettiği konfora yaslanarak sürdürmekte 1srar eden elitler için risk alanları giderek büyümektedir. Beck'in belirttiği gibi, riskin varlık kazandığı alanlar, sosyal bir bumerang etkisi oluşturur: Siyasal ve ekonomik düzeydeki seçkinler dahi, riskin çekim alanının dışında kalamaz (Beck, 2005: 37). Teorik düzeydeki bu analizi 2000 sonrası dönemin ekonomi-politiğine uyarlayan Yılmaz'a göre, Türkiye'de ve İstanbul'da 1990 sonrası muhafazakâr kesimin toplumsal yaşamda görünürlülügünün artması, orta sınıfların sayısal anlamda çoğaldıklarının göstergesi olarak okunabilir. Ancak Türkiye gibi ülkelerde orta sınıfın yükselen görünümü, olası krizlerde Batı ekonomilerinden gelişecek borç sarmalını daha yoğun yaşayacak bir kitlenin büyümekte olduğunun da habercisi. Bu nedenle İstanbul'da orta sinıfların yükseliş trendini kültürel bir içerikten ziyade, kaygan bir eşitsizlik zemininde ele almak mümkün. Nitekim orta sinıfların daha iyi bir yaşam olanağını kollayan ve sürekli buna uygun bir dil arayışı (Yılmaz, 2013: 104), politik seçkinler için daima bir "demokles kılıcı" hüviyeti taşımakta.

Ekonomi-politik düzeyde bu tür risk alanlarına, son dönemlerin emek piyasasında giderek etkisini arttıran "prekarya" olgusunu da eklemek gerek. Mevcut muhafazakar iktidarın Batı bloğuyla ilişkileri aktüel olarak çatışmacı bir zemine kaysa da; modern Cumhuriyet tarihi boyunca küresel kapitalizmle entegrasyonun en yüksek seviyede geliştiği bir dönemi deneyimliyoruz. Bu bütünleşme hikayesinin doğal bir varyantı olarak, geniş kitlelerin piyasanın kaygan ve güvencesiz kollarında bir "gelecek" arayışına yönelmeleri öne çıkar. Yaşanan deneyim, önceki dönemlerin mütevazi olduğu ölçüde sabit, istikrarlı ve uzun soluklu istihdam 
mecralarının daralması demekti. Diğer taraftan bu manzaraya, kamusal alanda "memuriyet" gibi nispeten belirli kitlesel-statü alanlarının "mülakat" tarzı patronaj ilişkilerine açıklı̆̆ eşlik etmekte. Gelinen noktada, metropol ortamlarında daha keskin bir görünüm kazanan prekaryan kitlenin üreteceği "riskin" boyutu da giderek artmakta.

Dolayısıyla muhafazakarlığın genç, kentli ve orta sınıflaşan yüzleriyle, prekaryan kitlenin beklentilerinin buluştuğu "rasyonel" zemin, günümüz politik seçkinleri için hayli trajik bir geleceği işaret etmekte. Özellikle 2017 referandumu ve yerel seçimlerin metropol kategorilerinde billurlaşan bu tablo, Türk modernliğinin rutinlerinden "kimlik siyaseti”nin kapsama alanlarında bir daralmayı da göstermekte. Nitekim muhafazakârlık paydasında buluşan toplumsal bloğun kamusal iletişiminde önemli bir arka planı oluşturan duygular siyasetinin keskin hatları, peyderpey aşınabilmekte.

Gelinen noktada bu çalışmada, 2000 sonrası dönemden itibaren Türk siyasetinde muhafazakâr siyasetin hegemonik konumunu sarsıcı etkiler taşıdığı düşünülen yerel seçimlerin sosyolojik etkileri analiz edilecektir. Araştırma boyunca yaşanan deneyim, retrospektif bir perspektifle 1950'lerden günümüze gelişen hatları izleyerek ortaya konacaktır. Aynı zamanda muhafazakar toplumsal bloğa ilişkin dönüşüm tezahürleri, politik sahaya temas eden boyutlarla sınırlı olarak incelenecektir.

\section{Milli Görüş ve İslami Hareketin Politik Serencamı}

Laik Cumhuriyet değerlerinin toplumsallaşma evresinde alttan alta bir dip dalga halinde yürüyen demokratikleşme ihtiyacı (Küçükyılmaz, 2009: 72), çok partili hayata geçildiği dönemde kamusal bir hüviyet kazanmıştır. Bu dönem aynı zamanda siyasal muhafazakârlığın da yükselişe geçtiği önemli bir eşik. Yavuz'a göre bu gelişmeyi belirleyen faktörler, altkültürlere kimlik sunulması, kentleşme ve sosyal sorunların etkisi, radikal İslamı 1lımlı İslamla dengeleme politikaları, demokratikleşme ve tercüme faaliyetlerinin etkisiydi (Yavuz, 2010: 87). Benzer olarak Akdoğan, politik arenada İslam'ın artan görünümünde, nüfus hareketleri ve sosyolojik değişimin etkisini vurgular. $\mathrm{Bu}$ açıdan kent ortamlarında ritmini yakalayan İslami hareket, bir kimlik vaadiyle ortaya çıkarak, geleneksellik ile modernlik arasında sıkışan kitleye aidiyet sunabilmekteydi (Akdoğan, 2000: 180). Ancak bu kimlikleşme süreci, bilişsel bir konteksin ötesine uzanarak; kent piyasa ortamında muhafazakarlığın hareketlilik kazanmasında önemli bir referans halindeydi.

Nitekim İslami hareketin merkezileşmesine etki eden bir diğer faktör, daha sonra adı İslami sermaye olarak kavramsallaştırılan, yeni bir birikim sürecinin işlemeye başlamasıydı. İlk icraatlarını 1970'lerle birlikte ortaya koymaya başlayan bu sermaye, mütevazi düzeyde başladığı metal, tekstil, ağaç, gıda, endüstri temelli tarım ve inşaat gibi alanlarda kompleks sistemler haline dönüşmüsştür. Süreçle birlikte Al Baraka Türk, Kuveyt Türk, Faisal Finans büyük çaplı bankacılık işlerini taşıyabilecek olgunluğa erişen, küresel sermaye grupları haline geldiler (Yaraşır \& Aygün, 2002: 198). Hareketin ivme kazanması aynı zamanda rekabetçi siyasi alanların oluşması, kamusal alanın genişlemesi ve harekete yeni entelektüellerin katılması süreçlerinin sonucu (Yavuz, 2011: 66). Bu dinamizmin politik dili ise, özelikle Milli Görüş Hareketi (MGH) tarafindan temsil edilmekteydi. 
MGH'nin seçmen tabanını taşra şehir ve kasabalarındaki muhafazakâr küçük burjuva esnaf, küçük tüccar, çiftçi ve zanaatkârlar oluşturuyordu (Yavuz, 2011: 68). Taşra merkezli ekonomik grupların MGH olan bu teveccühünde, büyük sermayeye yakın bir görüntü veren Süleyman Demirel'in Adalet Partisi'nden ümidin kesilerek, muhafazakar dokuya uygun bir siyasal örgütlenme biçimine ihtiyaç duyulması rol oynar (Küçükyılmaz, 2009: 74). Nitekim kültür, kimlik merkezli kaygıların yön verdiği bu kulvarda MGH, politik serencamı boyunca İstanbul merkezli kapitalist oluşumlarla ilgili rezervlerini korumuştur. Güçlü metropol sermayesi karşısında, küçük-yerel Türk sermayesini desteklemiştir (Özdalga, 2006: 50). Benzer olarak, "ülkedeki tüm sorunların Tanzimat'tan itibaren izlenen Batılılaşma politikalarından kaynaklandığını" savunmuştur. Sosyal adaletsizlik, ekonomik geri kalmışlık ve hatta demokrasi eksiklikleri gibi bir dizi yapısal problemin çözümü için Milli Görüş’ün önerdiği politika, bir çeşit İslamileştirme politikası olan manevi kalkınma idi (Çınar, 2010: 311).

Hareketin 1980 sonrası süreçteki temsilcisi olan Refah Partisi (RP) ise, çok daha farklı bir toplumsal tabana erişti. Kent yoksullarına, yukarı doğru sosyal hareketlilik içindeki yeni orta sınıf çalışanlarına ve özellikle de kentlerde yeni ortaya çıkan İslami girişimcilere ulaşarak, geleneksel seçmen tabanını genişletmeyi başardı (Yavuz, 2011: 80). Kentin yoksul kesimleriyle kurulan bu yoğun ilişki, 12 Eylül darbesiyle örselenen solun boşalttığı kamusal iletişimin sağ bir dil içinde yeniden formüle edilmesiydi (Alpman, 2016: 131). Yaşanan süreç, Cumhuriyet modernliğinin "kenara itilmiş" ve "dışlanmış" kesimlerinden oluşan çok katmanlı bir koalisyondu (Yavuz, 2011: 80). Bir diğer ifadeyle, Cumhuriyet boyunca istikrarlı olarak yönetim merkezinin kenarında tutulan ve hatta günün birinde sistemle hesaplaşmayı bekleyen geniş toplumsal kesimlerin MGH eliyle, ülkenin yasal siyasal ortamının içine çekilmesiydi (Küçükyılmaz, 2009: 76). Ancak RP'nin izlediği ve 12 Eylül öncesi süreçte daha çok solun temsil ettiği bu sert muhalif hat karşısında, devlet elitlerinin rutinleşen müdahaleleri de gecikmeyecekti. Kamuoyunda "postmodern darbe" olarak da anılan 28 Şubat kararları, çekirdeğini İslami hareketin oluşturduğu sistem-karşıtı cereyana dönük bir "balans ayarı"ydı.

Gelinen noktada hareket, 28 Şubat'la birlikte birçok sahada yeniden geriye çekilmek zorunda kald1. Ancak dönem boyunca İsami hareketin belki de en önemli avantajı, uluslarası konjonktürde serbest piyasa, hukuk devleti vb. alanlara dönük kurumsallaşma arayışlarının öne çıkmasıydı. $\mathrm{Bu}$ konjonktür dikkate alındığında, darbe cereyanı, "statükonun tecessüm etmiş hali olan TSK"nın vesayetini tartışmaya açan ve statükosunun sorgulandığı yeni bir dönemi beraberinde getirdi (Alpman, 2016: 131). Diğer taraftan, 28 Şubat sürecinde taşralı kebapçıların dahi iç düşman olarak damgalandığını gören geniş muhafazakar kesimde -asgari hak ve özgürlükleri garanti altına alan bir hukukun olmadığı durumda- kendi varoluşunu garanti etmenin başlıca yolunun güç kazanmak olduğu inancı giderek arttı (Çınar, 2010: 312). Bu yaklaşım, ilk planda siyasal İslam'ın yapısal toplumsal meselelerin halli için "güç alanlarına yerleşim" mottosuna uygun bir hat çizmekteydi. Ancak iktidar pratiği düzeyinde esaslı bir farklılaşma "arzusu"nun da habercisiydi. Süreç boyunca muhafazakarlığın siyasal ve entelektüel elitlerince, "Batı karşıt1-Müslüman milliyetçiliği" hattından "AB ve uluslarlarası toplumla entegrasyon" temelli politikalara evrilme arayışları öne çıkar. Bu dönüşüm özellikle 2002'de iktidara gelen AK Parti siyaseti ve hareketiyle varlık kazanmıştır. 


\subsection{AK Parti Deneyimi Etrafinda Merkezin Kalbine Yolculuk}

Yukarıda belirtildiği gibi, Ak Parti deneyimiyle öncelikli olarak, İslami hareket içerisinde tekelci hüviyetteki MGH'nin bölünmesi ve içinden bir grubun koparak, kendisini ideolojik olarak dönüştürme süreci yaşanmıştır. Burada MGH'nin Batı karşıtı, devletçi/kalkınmacı ve içinde barındırdığı milliyetçi öğelerden mümkün olduğunca arınıp, uzlaşmacı bir iktidar profili çizmesi amaçlanmıştır (Uzgel, 2010: 12). Nitekim siyasetin açtığı kanallardan muhafazakar kitlelerin eğitim ve daha sonraları iktisadi kaynaklar yoluyla Bourdieu'nun kullandığı anlamda sembolik ve kültürel sermaye edinmeleri; İslâmcılıktaki protest damarı aşındırmıştır (Bilici, 2004: 800). Gelişen dinamik sınıflar, 80 sonrası ekonomi-politiğin bir varyantı olarak, devlet kapitalizminden piyasa kapitalizmine geçişin ürünü olduklarından, piyasa ekonomisinin ve Türkiye'nin küresel ekonomiye eklemlenmesinin başlıca savunucuları haline geldiler (Yavuz, 2011: 76).

İkinci aşamada ise, Türkiye'deki liberallerle oluşturulan yeni hegemonik blok aracılı̆̆ıla Kemalist ideolojinin ve devletçi anlayışın dönüştürülmesi ve küresel-kapitalizm için "defolu” yönlerinin tasfiye edilmesi gündeme gelmiştir. Bir yanda 1lımlı İslamcılar, öte yanda arka planda TÜSİAD'1n, ama vitrinde liberal entelektüellerin olduğu bu hegemonik blok, 2000 sonras1 Türkiye'nin dönüşümünü üstlendi (Uzgel, 2010: 12-27). Süreç boyunca muhafazakârlık paydasında buluşan aktörler, dönemin "özgürlükçü ortamı"na uygun renk ve tonlara bürünerek sahne almıştır. Bir yanda yükselen yeni muhafazakar orta sınıf, STK'laşan İslami oluşumlar, öte yandan ise kapitalistleşen tarikatlar... Neredeyse tüm bu paydaşlar, "yukarıdan aşağıya bir İslamileştirmeyi değil; iktidardan pay almak, bürokratik-merkeziyetçi laik devletin kısıtlayıc1/engelleyici müdahalelerinden kurtulmak, yani serbestlik istiyordu ki; bu AKP'nin kullandığı negatif özgürlükçü liberal dilin temelini oluşturmaktaydı.” (Çınar, 2010: 312). Sürecin en önemli meşruiyet ayağı ise, Cumhuriyet elitlerince de bir "ideal" olarak benimsenen Batılılaşmanın güncel tezahürü halindeki AB üyeliğiydi.

Partinin devlet kurumları nezdinde meşruiyet arayışı, AB'ye yönelik demokratik normları kabul etmeye zorladi. İslami gruplar, 28 Şubat tecrübesiyle kendilerini iktidara taşıyacak tek yolun bu olduğunu anladıkları için, yeni demokratik anlaşmaları gönülsüzce bile olsa seküler gruplardan daha fazla destekledi (Yavuz, 2010: 9-10). Ancak madalyonun diğer yüzünde, daha sonraki dönemlerde "ulusalcı" olarak da kavramsallaştırılacak asker-sivil orta sınıf, kentli, modernist ve laik kesimlerde sürecin okunması bambaşka bir anlama bürünmekteydi. Nitekim politik muhafazakarlığın en ön cepheden seslendirdiği postmodern ve küresel dinamikleri, doğrudan devleti, yani kendi konumlarını hedef alan bir süreç olarak değerlendireceklerdir. Ulusalcılar bu süreçte $A B$ üyelik sürecine de kuşkuyla yaklaşmış ve insan haklarını negatif bir süreç olarak algılayarak Türkiye'nin bölünmesiyle bağlantılandırdı. Entelektüel ve politik seçkinleri aracılığıyla, Türkiye'de AB ve ABD karşıtlığının öncülüğünü yapmaya başladılar (Uzgel, 2010: 27). Türklük ve millilik ethosuna yaslanarak, kozmopolitan dünyaya açılan girişimlere karş1, kapanmacı bir tasavvuru öne çıkarmıştır. Sözgelimi dönem boyunca ülke sathında "bestseller" boyutuna kavuşmuş kültürel üretimlerin ("Çılgıı Türkler", "Bye Bye Türkçe” vb.) ulusalcı kaygılara yaslanarak gelişmesi bu arayışın bir izdüşümüydü.

Ancak kültür sahasının bu topraklarda toplumsal eğilimleri yönlendirmedeki kısıtlı etkilerini dikkate aldığımızda, laik seçkinlerin öngördüğü "distopya", hergeçen gün bir gerçeklik olarak kendisini göstermekteydi. Nitekim toplum katında giderek ivme kazanan muhafazakâr dalgaya 
set çekme arzuları, giderek politik sahanın sert dili etrafında temsil edilmekteydi. Özellikle 367 krizi ve Cumhuriyet Mitingleri'ne yansıyan "agresif manzara", dönem boyunca gelişen bir dizi seçimin toplumun yerleşik orta sınıf katmanlarınca "distopik bir geleceğin ayak sesleri”" olarak okunduğunu göstermekteydi. Bu distopyanın karşllık geldiği durum ise, "laik-Cumhuriyet sisteminin değişimi”nden başkası değildi.

Diğer taraftan sarmalın diğer kutbu, giderek "merkezileşme" kulvarına yerleşen bir hikayeye sahne olmaktaydı. Seçimlerin yerel ve genel boyutlarına ilaveten, Anayasa değişikliğini içeren referandumların da dahil olduğu bu kesintisiz zaferler, Cumhuriyet modernleşmesinin hiyerarşik tablosunda köklü değişimleri tetiklemekteydi. Muhafazakarlık, siyasal ve toplumsal sahalarda "merkez"e yerleşirken, Erdoğan liderliği ise, Weberyen anlamda bir "karizma" olarak formüle edilecekti (Aktay, 2011). Süreçle birlikte muhafazakarlığın entelektüel ve politik seçkinleri, "Yeni Türkiye" söylemiyle bir hegemonya arayışını da hızlandırmıştır. Nitekim 2010'lara değin "kitle partisi"nin zorunlu kıldığı çoğulcu-esnek dil; giderek hegemonya kovalayan ve toplumsal manzarayı köklü bir şekilde dönüştürmeyi arzulayan Schmittyen kimlikçi siyasetlere bırakmıştır. Sürecin uzun vadedeki toplumsal maliyeti ise, çatışmacı-ötekileştirici siyasal dilin egemen olması (Öztürk, 2019: 275-279) ve İslam'ın bir kimlik hattı etrafında araçsallaşmasıydı.

\section{Hegemonya Arayışlarının Kavşağında Kimlik Siyasetleri}

Muhafazakâr siyaset özelinde "dindar-kindar nesil"3, "liberallerin lüzumsuz olduğu inşa dönemi" " gibi dost ve düşman ayrımları üzerinden gelişen Schmittyen kimlik siyaseti, birleşme ya da ayrışmanın en uç yoğunluk derecesini ifade etmektedir. Schmitt'e göre, özellikle politik karşıtlık en yoğun ve uç karşıtlıktır. Siyasetin yön vermesiyle gündelik ya da kamusal alan, "dostdüşman” keskinliği etrafında siyasallaşır (Schmitt, 2018: 57-60). Taggart'a göre popülist siyasetin eriştiği bu imtiyaz, kitle gerçekliğinin esnek ve bükülgen ontolojisinden kaynaklanır. $\mathrm{Bu}$ yaklaşıma göre, popülizm şekillendirilebilir araçlara ihtiyaç duyar ve kitleler de tam böyle bir araçtır. Nitekim popülist siyasetler, "kim olmadıkları"na dair anlatıyı, kim olduklarından çok daha fazla vurgularlar. Belirli toplumsal grupların lanetlenmesi ve seçkinlere duyulan nefret, popülistlere bir düşman sağladığı gibi; seslendikleri tabanda kimlik oluşturma politikalarının da önemli bir parçasıdır (Taggart, 2004: 116-119). Nitekim muhafazakâr elitlerin geniş kitleleri mobilize kılabildiği bu repertuarlardan biri de, "Yeni Osmanlıcı" söylemdi.

Tokdoğan'a göre Yeni Osmanlıcılık, stratejik bir politik anlatı olmanın ötesine uzanarak, gerek iktidar seçkinleri gerekse toplumsal taban tarafindan hevesle kucaklandı. Bu anlamda Yeni Osmanlıcılık, toplumsal tabanın arzularını, hırslarını, öfkelerini açığa çıkarıp, dönüştürüp, onları harekete geçirici bir işlev gördü (Tokdoğan, 2018: 17). Aynı zamanda geniş muhafazakar kitledeki "küresel liderliğe duyulan arzuyu" (Tükel Pakel, 2017: 128) da bir ölçüde ifade etmekteydi. Benzer bir motivasyonla araçsallaştırılan İslam, bir medeniyet ya da evrensel bir yaşam tarzının ötesine uzanarak; politik varoluşun gerekçelendirildiği bir grup kimliği hüviyetine bürünür (Çelenk, 2017: 30-31). Ancak siyasal İslam'ın geçmişten günümüze politik sahaya biçtiği varoluşsal anlam dikkate alındığında, bu tür yöntemlerin tesadüfen gelişmediği rahatlıkla

\footnotetext{
${ }^{3}$ https://www.hurriyet.com.tr/gundem/secilmisi-atanmisa-kul-etmeyiz-19956550

${ }^{4}$ https://t24.com.tr/haber/babuscu-onumuzdeki-10-yil-liberaller-gibi-eski-paydaslarimizin-kabullenecegi-gibiolmayacak,226892
} 
anlaşılabilir. Nitekim siyasal İslam, "çözümü devlette gören, değişimi siyasal iktidarın gücünde ve etkili araçlarında arayan, yukarıdan aşağıya Müslümanlaşmayı öngören, resmi bir din görüşüne dayanan total eğilimleri baskın” bir perspektife karşıllk gelmekte (Akdoğan, 2004: 92). Dolayısıyla toplumsal alanın tasarımıyla ilgili beklentilere, siyasal tasavvurlar yön vermekte. Temel strateji ise, özellikle modernleşme süreçlerinin kolektif hafızada bıraktığı tortulara yaslanan bir siyasal pragma etrafinda gelişmekte.

Nitekim "siyasal İslam'ın otoriter modernleşme deneyimlerinin tetiklediği küskünlüklerden yararlanarak iktidara gelme ve statükoyu y1kma hedefi güden bir gündem peşinde olduğu" düşünüldüğünde, Ortadoğu merkezli birçok otoriter rejim için gerçek bir tehdit olarak görülmekteydi. Bu konuda öne çıkan çözümler ise, İslamcı güçlerin şu ya da bu şekilde politik sisteme dahil edilmesiydi (Akdoğan, 2000: 216). Ancak Yavuz'a göre, İslami hareket tecrübeleri arasında yapılacak bir karşılaştırma, onların Janus yüzlü olduklarını ortaya koyacaktır. Yani bu hareketler bir taraftan modern, sosyal ve siyasal açıdan "ilerici", demokrasi ve ekonomik gelişme taleplerini dolaşıma sokarken; uzun vadede muhafazakâr ve otoriter olup, toplumda sıkı bir moral-dinsel kodun varlığını talep ederler (Yavuz, 2005: 29). Bu konuda Türk siyasetine dair hafızada "mizah" konusu olarak da değerlendirilen, Erbakan'ın sarfettiği "diğer partilerin seçmenleri, bizim ise inananlarımız var" söylemi, hayli çarpıcı bir örnek olarak karşımıza çıkar (Küçükyılmaz, 2009: 106)

Yavuz'a göre, ekonomik ve sosyal liberalizasyon, İslami hareketlere öncelikle kendi gündemlerini kamusal düzeyde dolaşıma sokma imkanı tanımıştır. Ancak sürecin beraberinde getirdiği çoğulculuk ve geleneksel sosyal kontrollerin parçalanma belirtileri karşısında hareketlerin son derece rahatsız olduğu bilinmektedir. Küreselleşmenin bu türden kaçınılmaz tesirleriyle, İslami uygulamaların ve kimliğin çoğulcu okumalara imkân vermeyecek mutlakçı bir yorumuna yönelmişlerdir (Yavuz, 2005: 49). Gerçekten de İslami hareketlerin merkezileşme serencamına dair bu analiz, AK Parti tecrübesi 1şı̆̆ında değerlendirildiğinde hayli anlamlı bir manzara ortaya çıkmakta. İktidar yolculuğunun ilk etaplarında sivil-asker ilişkilerinden Kürt meselesine, demokratikleşmeden ekonomik kalkınmaya kadar bir dizi sorunu, toplumsal mutabakata yaslanarak çözeceğine ilişkin vaatleri hayli geniş cephelerden karşlık buldu. Aynı zamanda politik rasyonalitenin çizdiği bu rota doğrultusunda, İslamcıllğın tarihsel bakiyesinden ve itirazlarından hızla uzaklaşarak, çerçevesini muhafazakarlı̆̆ın belirlediği bir devlet ve iktidar aklı ile hareket etti (Alpman, 2016: 131). Diğer taraftan uluslararası toplum ve kurumlarla geliştirilen yakın ilişkilerin doğal bir varyantı olarak, ekonomik-sosyal istikrar hanesinde çarpıcı başarılar yakalanıyordu.

Ancak muhafazakar elitlerin neredeyse tüm sahalarda yansıyan bu tür pozitif görüntüleri okuma refleksi, 2010 sonrası konjonktürle birlikte dönüşmekteydi. $\mathrm{Bu}$ dönemde özellikle yargı bürokrasisindeki hegemonya değişimini içeren referandumda $\% 58^{\prime}$ 'lik zafer ve akabinde gelişen ulusal seçimlerinin \%50'ye yakın bir başarıyla kazanılması, önemli eşikler olarak karşımıza çıkmakta. Buna ilaveten aynı dönemde Arap Baharı rüzgarının start almasıyla, Ortadoğu'daki muhalif kitle ve örgütlerin doğrudan bir referansı haline gelinmekteydi. Gelinen noktada tüm bu koşullar, muhafazakarlığın politik ve entelektüel seçkinlerince "hegemonya tesisine giden bir imkân alanı" olarak okunuyordu. Bu arzunun yerel siyasal gündeme yansıması "Başkanlık" tartışmaları etrafında formüle edilirken; kültür sahasında ise dindar nesil tahayyülü, İmam Hatip 
modelinin yaygınlaştırılması ve Osmanlıca öğrenme-öğretme arzusu gibi bir dizi hat etrafında gelişti.

Diğer taraftan iktidar tekniğinde hegemonik arzulara ilaveten, istikametin "keyfilik" belirtileri taşıyan eylemlere sahne olmasının metropol dünyasındaki yankıları da gecikmeyecekti. Özellikle metropollerin yerleşik-seküler orta sınıf hanelerinde gelişen korku ve öfkenin yansıma imkanı bulduğu ilk dalga ise, Gezi Süreci'yle ortaya çıkmıştır. Sürecin ana hattı olarak taraflarda yerleşen kutuplaşma cereyanı, özellikle muhafazakar siyaset için keskin bir yörünge değişikliğine yol açmaktaydı. Bu doğrultuda uzun yıllar uluslararası toplum ve kurumlar nezdinde "model bir hareket" olma hüviyetinin raftan kaldırıldığının sezilmesiyle birlikte, anaakım politikalarda bir makas değişimi yaşanmıştır. İdeolojik referanslar giderek reformist-Batıcı eksenden, "yerlici ve milli” bir eksene kaymaktaydı. İktidar sahasında yaşanan bu baş döndürücü trafiğe, günümüz kamuoyunda Fetö olarak adlandırılan grubun 15 Temmuz 2016'daki darbe girişimi de eklendiğinde, yerlilik ve millilik eksenli siyaset, "varoluşsal bir zorunluluk" olarak kamuoyuna sunulmaktaydi.

Kuşkusuz muhafazakarlığın erken Cumhuriyet'ten itibaren deneyimlediği yabancılaşma, bu kesimde yerlilik merkezli damarı uzun soluklu kılmıştır. Aynı zamanda bu deneyim, MGH'de olduğu yerliliği temel alan siyasal hareketlere kaynaklık etmiştir. Ancak yerlilik, Akın'a göre kendi halinde bir pratiktir. Yerliliği koruma ve sürdürme tahayyülünde olsa bile, "yerlici siyaset" de, yerliliği yabancılaştırma riskini barındırmaktadır (Akın, 2013: 55). Nitekim 2010 sonrası dönemden itibaren muhafazakâr kadrolarda birden alevlenen yerlici hassasiyet, "reformist-Batıc1 siyasal kulvarda yolun sonuna gelindiğii"ne dair inancın izlerini taşır. İktidar bloğunda bu keskin dönüşümün izleri, birçok mecrada rahatlıkla görebilir. Sözgelimi iktidar politikalarının belirlendiği ve kamuoyuna sunulduğu epistemik mutfağın önemli aktörlerinden SETA'da yer alan bir bir analiz, hayli anlamlı veriler içermekte. Raporda, Kılıçdaroğlu'nun Haziran 2017'de başlattığı "Adalet Yürüyüşü", öncelikli olarak "yerli ve milli normali yerinden etmeye yönelik karşı bir hamle" olarak sunulmakta. Yazının devamında italik olarak gösterdiğimiz ifadeler ise, iktidar sathındaki ideolojik makas değişiminin izlerini net bir şekilde taşımakta:

“Batıcı bir dil üzerinden işleyen ve etkisini yitirmiş 'özgürlükler' vurgusunun yerine iktidarın yerli ve milli söylemiyle başa çıkabilecek ölçüde yerli bir politika olan 'adalet' siyaseti benimsendi. Kılıçdaroğlu'nun Maltepe mitingindeki konuşmasında yerlilik açısından 'adalet' başlığının altını dolduramayan, halen Batıcı özgürlükler siyasetinin kodlarıyla donatılmış bir içeriğe sahipti (Aslan, 2017: 101).

“Özgürlük” kavramına yüklenen bu pejoratif anlam, milliyetçi-ulusalcı tasavvurda istikrar kazanmış mecralar tarafından dile getirildiğinde nispeten anlaşılabilir bir düzeye sahip. Ancak bu tür "düşünce kuruluşları"nın yüzleşmek istemediği ya da hasıraltı ettiği gerçeklik ise, söz konusu yaklaşımın muhafazakâr siyasetin ittifak halinde olduğu koalisyonlara göre bükülebilen bir nitelik kazanması. Nitekim raporda yer alan bir başka fasılda dile getirilen "medeniyet" söyleminin de içi, ideolojik dönüşümü yansıtan ifadelerle yüklü: 
“2009'lardan 7 Haziran 2015'e kadar süren Medeniyet söylemi, Türkiye'yi kendi içine ve dışına doğru genişletme hamlesidir. Yerli ve milli siyaset ise, bu amacın gerçekleştirilebilmesi için öncelikle Türkiye'nin demokratik bir toplum yapısına kavuşmasına direnen unsurlardan arındırlması gerektiğinin altını çizen bir hamledir. (Aslan, 2017: 99)

Yerlilik ve millilik temelli siyasetin epistemik meşruiyetine odaklanan SETA raporunun bu faslı, hayli paradoksal ifadelere sahip olsa da, yaşanan ideolojik makas değişimini birkez daha netleştirmekte. Sözgelimi önceki satırlarda Batı orijinli bir kavram olarak sunulan "özgürlük", yerli ve milli merceklerle bakıldığında tasnif dışı kalabilmekteydi. Ancak aynı yazıda, tarihsel ve toplumsal düzeyde Batılı bir tecrübe olarak dünya sathına yayılan "demokratik toplum", bir ideal olarak karşımıza çıkmakta. İdeolojik makas değişimi ise, bu "idealin" gerçekleşme safhasında iktidar karşıtı cephede yer alanların "arındırılmasının gerekliliği" ni ${ }^{5}$ vurgulayan yaklaşımda açığa çıkmakta.

Gelinen noktada yerli ve milli siyaset varoluşsal bir bağlama kavuştukça, partiye bağl1lık da kutsal devlet mistifikasyonuna denk bir hüviyet kazanmaktaydı. Bu çerçevede partiden yana olmak ile olmamak arasındaki kalın çizgi, Türk sağına özgü kodlarla yeniden tanımlandı. Hainlik, ajanlık, bölücülük, dış-iç mihrak, art niyetlilik hatta dinsizlik kodları (Alpman, 2016: 131), yerli ve milli hattın dışındaki geniş kesimler için kategorik tanımlama biçimleri olarak öne çıkmaktaydı. Diğer taraftan iktidar blokunun yenilenen sakinlerinde otoriterleşmenin dozu arttıkça, öncelikli refleksler metropollerin pragmatik-seküler hanelerinde gelişmekteydi. Taşkın'a göre, son yerel seçimlerde AKP-MHP blokunun metropollerde yaşadığ 1 dramatik tablonun bir nedeni de budur. Ona göre, AKP-MHP bloku devletçi-milliyetçiliğe yaslandıkça giderek sayıları artan toplum kesimlerini yabancılaştırmaya başladı (Taşkın, 2019). Ancak metropollerde ivme kazanan bu dinamizmin çekirdeğinde seküler kimlik tasavvuru yer alsa da (Ertit, 2019), muhafazakarlığın genç-eğitimli ve kentli katmanlarında da filizlenen bir arayışı temsil etmekte.

\section{Tıkanan Siyasetin Metro-politiği}

Kuşkusuz iktidar bloğunda yerli ve milli temelli siyaset tekniğinin metropol dünyasını ikna kapasitesindeki düşüşün birçok referansı bulunmakta. Bu açıdan çalışmanın sınırlı kapsamı da dikkate alınarak, metropollerde dalgalanan itiraz dilinin arka planı, ana hatlarıyla ortaya konulmaya çalışılacaktır. Öncelikli olarak vurgulamak gerekir ki, son yerel seçim sonuçlarına göz gezdirildiğinde Türk modernleşmesinin keskin siyasal kamplarının "metropol duyarlılı̆̆ı"nda birleştiği görülmekte. Buna göre Kürt-Türk, laik-muhafazakâr gibi rutin ayrımların buharlaştığı, iktidara mesaj verme arzusunun vitrine çıktığı bir refleks, giderek siyasal alanı donatmakta. Farklı ideolojik ve siyasal kampların buluştuğu bu zemin, öncelikli olarak ekonomik tablodaki gerilemeyle beraber tetiklenen hayli "rasyonel ve pragmatik" tepkilere yaslanmakta. Buna ilaveten zikredilen kozmopolitan blok, "parti patronajı" olarak kavramsallaştırılan politikalardan duyulan rahatsızlığa karşı da giderek ses vermekte. Parti patronajı, toplumsal yaşamdaki firsat ve

\footnotetext{
${ }^{5}$ Kuşkusuz siyasal pratiğin "arındırma" merkezli işleyişinin ne tür bir düzen arzusunu ortaya koyduğuyla ilgili özellikle 20. yüzyıl dünyası hayli anlamlı tecrübelere sahip. Ancak kavramın işaret ettiği tasavvura dair bir analiz girişimine, çalışmanın sınırlılıkları dikkate alındığından yer verilmeyecektir.
} 
kaynak alanlarının çeşitli yollardan oluşturulmuş bir ă̆ içinde ve karşılıklı kabul görme temelinde "tercih edilen" bireylere, gruplara aktarılmasıdır. Sarıbay'a göre, bu tür tek taraflı aktarımların hacmi ne kadar artarsa, o kadar toplumsal paylaşımdan kaçınılır (Sarıbay, 1998: 24). Bir açıdan Weberyen "dışlayıcı kapanma" eğilimleriyle örtüşen bu tür patronaj ilişkilerinin mevcut iktidar tekniklerindeki kapsamı, birçok branşta KPSS birincilerinin dahi memuriyet hakkına kavuşamadığ 16 ekstrem boyutlara varabilmekte.

Ekonomi-politik dinamiklerin metropol dünyasında iktidar-karşıtı dalgaya yön verdiği bir diğer enstrüman, "prekaryalaşan kitle" gerçekliğidir. Standing'e göre prekarya, "precarious" (güvencesiz) sıfatı ile "proletariat (proletarya) isminin birleşmesiyle oluşan yeni bir terimdir. Çalışmasında prekaryanın uzun bir analizini gerçekleştiren Standing, prekaryayı öncelikli olarak klasik işçi sınıfı olan proletaryadan farklı bir bağlamda değerlendirir. Proletarya denildiğinde akla uzun dönemli, istikrarlı, sabit zamanlı ve ileriye dönük olarak işçinin ne kadar ve nasıl ilerleyebileceği açıkça belli olan işlerin bulunduğu, sendikalaşmanın olduğu, kolektif sözleşmelerin yapıldığı bir toplum akla gelir. Diğer taraftan Standing'e göre prekaryalar, orta sınıf da değildir. Zira bu sınıftan insanların sahip olması beklenen sabit ya da öngörülebilir bir maaş, statü yahut çeşitli haklara sahip değildir. Prekaryan kitlenin oluşumu, küresel kapitalizmin toplumlara dayattığı "esnek emek" dinamiğine yaslanır. Risk ve güvencesiz hallerin taşıdığı maliyet ise, fertlerin kendileri ve ailelerine yükleniyordu. Bu eğilimlerin küresel kapitalizmin başlıca tekniği haline gelmesiyle herhangi bir istikrara sahip olmayan ve bütün dünyaya yayılmış milyonlarca kişiyi barındıran küresel bir prekarya tabakası ortaya çıkmıştır. Süreçle birlikte prekarya, giderek tehlikeli bir sınıf halini almaktadır (Standing, 2019: 11-21). Nitekim prekaryan tabakanın Türkiye'de en görünür olduğu mecra olarak metropoller, güvencesizleşen ve daralan istihdam alanlarına yönelik hoşnutsuzluğun adresi olarak mevcut iktidar blokuna yönelmekte.

Diğer taraftan prekaryan kitlenin "gayrimemnun" eğilimlerinin yöneldiği adres hanelerinde, gündelik ya da kamusal yaşamın giderek parçası haline gelen kolektif gruplar da yer almakta. Bunların başında ise, göçmen-sığınmacı-mülteci üçgeninde buluşan "beklenmeyen misafirler" (Kartal\&Manço, 2018) gelmekte. Standing'e göre bu atmosferde yerli toplumun emekçi üyeleri, "sosyal yardım beleşçisi”olarak damgaladığı kitleyi kendisinin elde edemediği şeyleri almakla suçlamaya meyilli olabilir. Aynı zamanda göçmenlerin daralan istihdam sahasında daha iyi işleri kaptığını ve sosyal yardımlar konusunda tepeye çıktığını kolaylıkla düşünecektir (Standing, 2019: 49).

Sennett de Amerikan toplumu odaklı bir çalışmasında, göçmen hoşnutsuzluğunun artan ivmesinden bahseder. Öncelikli vurgusu, "yabancıların çalışkan, doğma büyüme Amerikalıların kuyusunu kazması" korkusunun 19. yüzyıla kadar inen köklere sahip olmasıdır. Bu yüzyılla birlikte, düşük ücrete çalışmaya razı olan yoksul ve vasıfsız göçmen işçilerin "diğerlerinin işlerini elinden aldığına" inanılırdı. Sennett'e göre, bugün küresel ekonomi, bu eski korkuyu tekrar canlandırıyor ve insanlar sadece vasıfsız işçilerin değil; küresel emek piyasasının dalgalarına kapılan orta sınıfların ve profesyonellerin de tehdit altında olduğuna inanıyor. Sözgelimi bir çok Amerikalı doktor, Üçüncü Dünya ülkelerinden gelen "ucuz doktor" dalgası yüzünden kendi iş güvencelerinin sigorta ve sağlık şirketlerinin tehdidi altında olduğunu düşünüyor (Sennett, 2016:

\footnotetext{
${ }^{6}$ https://www.haberler.com/kpss-turkiye-birincisi-mulakatta-elendi-11730185-haberi/ http://www.cumhuriyet.com.tr/haber/kpss-birinciligi-atanmasina-yetmedi-1723600
} 
145-146). Kuşkusuz göçmen hoşnutsuzluğuna dayalı bu küresel trend, bugün sayıları 4 milyona ulaşmış sığınmacının bulunduğu ülkemizde de etkisini göstermekte. Özellikle de iktidar bloğunun kaybettiği İstanbul seçimi sonrasında sığınmacılara dönük aniden "sertleşen" politikalarında... Nitekim ortaya çıkan manzara, göçmen-karşııı tsunaminin "kontrollü yerli ve milli limanlar"a uzanan etkilerinin kabulü ${ }^{7}$ olarak okunabilmekte.

Muhafazakar kadroların metropolün rasyonel eğilimleri karşısında tıkandığı bir diğer alan, "mağduriyet temelli kutuplaşma" siyasetidir. Geçmişten günümüze siyasal İslam'ın kitleleri etrafinda bloklaştırmasında istikrarlı olarak müracaat ettiği, "sessiz muhafazakâr-mütedeyyin çoğunluk ve aktif Batıcı-seküler azınlık" denklemi büyüsünü nispeten yitirebilmekte. Taşkın'a göre, son yerel seçimlerle AK Parti'nin sağ popülizmini besleyen mağduriyet algısının altındaki halı daha da çekilmiştir. Seçmen, tepedeki karşıtlığa dayandırılan kutuplaştırıcı dili anlamsız kılacak tercihlerde bulunmuştur (Taşkın, 2019). Nitekim metropollerin siyasi haritasının son yerel seçimlerde değişimi, muhafazakar duyarlılıkta buluşan birkısım seçmenin de parçasını oluşturduğu çok cepheli kentsel muhalefetin etkisiyle gelişmekteydi.

$\mathrm{Bu}$ açıdan metropollerde yükselen itiraz kanallarını besleyen bir diğer havzayı, muhafazakar duyarlılıkta buluşan geniş kitleler oluşturmakta. Özellikle de muhafazakarlığın kozmopolitan metropol ortamlarında yaşayan ${ }^{8}$, genç, eğitimli ve dünyaya açık katmanlarında... Bu açıdan İstanbul, Ankara, Adana, Antalya gibi büyükşehirlerde belediye başkanlıklarınının el değiştirmesi, Bursa'da ise oy makasının önemli ölçüde kapanması, sözkonusu kitlenin tercihlerinden bağımsız okunamaz. Bu gruptakilerin hatırı sayılır bir kısmının siyasal arenada tansiyonun sürekli artan temposu karşısında ortaya koydukları "yabancılaşma", muhafazakar elitler için hayli netameli bir geleceğe işaret etmekte. Nitekim başkanlık süreciyle birlikte, "bloklaşan siyasal rekabet"in \%51 merkezli çıtası, "bıçak sırtı"nda gelişen sonuçlara sahne olmakta.

\section{SONUÇ}

$\mathrm{Bu}$ araştırma, siyasal iktidarın 2019 yerel seçimlerinin metropol kategorilerinde yaşadığ tıkanıklığın arka planındaki bir dizi toplumsal dinamiğe odaklanır. Yerel seçimlerin gösterdiği simgesel harita, 21. Yüzyılın ilk yıllarından itibaren Türk siyasetinin hegemonik aktörü halindeki muhafazakar siyasete dönük hayli anlamlı mesajlar içerekte. Aynı zamanda son dönem Türk siyasetine hakim birçok ezberin bozulduğunu resmetmekte. Bunların başında ise, 2013 Gezi Olayları'ndan itibaren muhafazakâr elitlerin siyasal arenada sıklıkla müracat ettikleri kutuplaşma cereyanı gelmekteydi. Bloklaşan siyasetle birlikte taraflar arasındaki tansiyonun hergeçen yükseldiği zemin, muhafazakarlık paydasında buluşan geniş kitlelerin AK Parti siyaseti ve hareketi etrafinda bütünleşmesini sağlıyordu. Nitekim genel seçimlerden anayasal gelenekte topyekün sistem değişimlerini içeren referandumlara uzanan hayli keskin virajların alınmasında kutuplaşma dilinin etkisi yadsınamaz.

\footnotetext{
${ }^{7}$ https://www.bbc.com/turkce/haberler-dunya-49416431

${ }^{8}$ Nitekim 2017 referandumundan günümüze dair gelişen politik harita, etno-kültürel ve yaşam tarzı düzeyinde kozmopolitan nitelikten uzak Konya ve Kayseri gibi iç bölgelerdeki metropol alanlarında, iktidar bloğunun \%60-70 skalasında rıza üretimini sağladığını göstermekte.
} 
Ancak toplumsal değişimlerin hızı karşısında, popülist siyasal mühendisliğin de "çaresiz" kaldığı durumlar oluşabilmekte. $\mathrm{Bu}$ anlamda uzun yıllar kitleleri seferber kıldığı retoriklerde, Weberyen deyimle "büyü bozumu" yaşanabilmekte. Nitekim son dönemlerde kozmopolitan şehirlere yansıyan seçim sonuçları, kimlik merkezli siyasetin özellikle yöneldiği (muhafazakar) adreslerde dahi büyüselliğini yitirdiğinin işaretleriyle yüklü. Diğer taraftan yaşanan süreç, hem muhafazakar tabanın kendi iç yörüngesini hem de toplumsal dünyanın tüm katmanlarını içeren boyutlara sahip.

Kuşkusuz metropollerde aktifleşen yeni toplumsal fay hatlarının gelişiminde, özellikle 2000 sonrası dönemin ekonomi-politik dinamikleri etkili olmakta. Bu çerçevede serbest piyasa ekonomisinin sunduğu firsat alanlarınlarıyla eşzamanlı olarak iktidar aygıttyla kurulan patronaj ilişkileri, muhafazakâr cephede hayli yoğun "sıçrama" hikayelerine sahne olmaktaydı. Süreçle birlikte orta sınıflaşma, bireyselleşme hatta sekülerleşme dinamiklerinin sözkonusu kitlede ivme kazandığı görülmektedir. Ancak iktidar deneyimiyle taşınan bu dalga, bir bumerang etkisi göstererek mevcut iktidar kadrolarının politikalarında "rasyonalite kaybı"nı sezdiği ölçüde ondan uzaklaşabilmekte. Nitekim seçim sonrası süreçle birlikte, başlıca hedef kitlesinin sözkonusu kentli-rasyonel tabakanın oluşturduğu iki yeni parti muhafazakar blokta sahne almaktadır. Diğer taraftan rasyonalite merkezli bu uzaklaşma, Cumhur ittifakı olarak adlandırılan muhafazakârmilliyetçi cephenin de ötesine uzanan bir kapsama sahip. Sözgelimi metropoller bünyesinde gelişen "şehirli milliyetçilik", "prekarya" vb. dinamikler dikkate alındığında, alternatif toplumsal cephenin bileşenleri hergeçen gün çeşitlenmekte.

Şehirli milliyetçilik vurgusu öncelikle, "kamusal alandaki dağılımların ve paylaşımların keyfilikten arınarak kurumsal, hukuki bir yörüngeye kavuşması" talepleri etrafında formüle edilmekte. Diğer taraftan bu tür rasyonel taleplerle birlikte, kitle reflekslerinin de yön verdiği bir duygu siyaseti de hakim olabilmekte. Kolektif bilincin belirleyici olduğu bu zeminde, metropol dünyasında giderek görünüm kazanan sığınmacılar/mülteciler önemli bir adres halinde. Suriyeliler başta olmak üzere küresel dünyanın daha çok "kaybeden" tabakaları, parçası haline geldikleri metropol yaşamını "istikrarsızlaştırma", "öngörülmez kılma" gibi argümanlarla değerlendirilmekte. Göçmen kitleye dönük bu hoşnutsuzluk, aynı zamanda bir dizi ekonomipolitik arka plana yaslanarak varlık kazanır. Bunların başında ise küresel kapitalizmin giderek emek piyasasını güvencesizleştiren, istikrarsızlaştıran yüzüyle beraber taşınan prekaryan kitle yer alır. İstihdam alanlarının geçici, esnek ve kaygan bir zemine kavuşmasıyla geniş kitlelerin deneyimlediği refah kaybı, prekaryan bilincin kökleşmesinde önemli enstrümanları oluşturmakta. Artan hoşnutsuzluk, öncelikle göçmen/sığınmacı kitleler üzerinden kendisini göstermekte. Ancak duygu siyaseti ve ekonomi-politik dinamiklerin buluştuğu bu eleştirel hat, Türk siyasal yaşamının bundan sonraki yörüngesinin belirlenmesinde, önemli bir potansiyel olarak varlık kazanmakta.

\section{Etik Standart ile Uyumluluk}

Çıkar Çatışması: Yazarlar herhangi bir çıkar çatışmasının olmadığını beyan eder.

Etik Kurul İzni: Bu çalışma için etik kurul iznine gerek olmadığını beyan ederim.

Finansal Destek: Yok

Teşekkür: Yok. 


\section{KAYNAKÇA}

Akdoğan, Y. (2000). Siyasal İslam, İstanbul: Şehir Yayınları.

Akdoğan,Y. (2004). AK Parti ve Muhafazakar Demokrasi, İstanbul. Alfa Yayınları.

Akın, M. H. (2013). "Yabancıda Aranan Yerlilik”, Sosyoloji Divanı, Sayı:1.

Aktay, Y. (2011). Karizma Zamanları, İstanbul. Timaş Yayınları.

Alpman, P. S. (2016), "Harikalar Diyarından Muhafazakâr Masallar”, Öteki Muhafazakârlık, Ed. A. Çağlar Deniz, Ankara: Phoenix Yayınları.

Aslan, A. (2017). "Yerli ve Milli Siyaset", Kuruluşundan Bugüne AK Parti, Çağlar İ. \& Alan, A. (Der.), İstanbul: Seta Kitapları.

Ulrich, B. (2005). Risk Society, London: Sage Publication.

Bilici, M. (2004). "Küreselleşme ve Postmodernizmin İslâmc1lı Üzerindeki Etkileri”, Modern Türkiye'de Siyasi Düşünce:İslâmcıllk, Cilt:6, İstanbul: İletişim Yayınları.

Çelenk, A. T. (2017). Türk Sağının Düşünce Atlası, İstanbul: Mahfil Yayınları.

Çelik, C. (2013). “Taşranın Değişen Sosyolojisi”, Taşra Fragmanları, Sosyoloji Divanı Dergisi, Sayı:1.

Çınar, M. (2010). “AKP ve İslami Hareketler: Defansif ve Dağıtıcı İktidar Kardeşliği”, AKP Kitabl, Uzgel, İ. \& Duru, B. (Der.), Ankara: Phoneix Yayınları.

Ertit, V. (2019). Sekülerleşme Teorisi, Ankara, Liberte Yayınları.

Kartal B. \& Manço U. (2018). Beklenmeyen Misafirler: Suriyeli Siğınmacılar Penceresinden Türkiye Toplumunun Geleceği, Londra: Transnational Press London.

Küçükyılmaz, M. (2009). Türkiye'de Siyasal Katılım, İstanbul: Birey Yayıncılık.

Özdalga, E. (2006). İslamcıllğın Türkiye Seyri, Çev: Gamze Türkoğlu, İstanbul: İletişim Yayınları.

Özet, İ. (2019). Fatih-Başakşehir: Muhafazakâr Mahallede İktidar ve Dönüşen Habitus, İletişim Yayınları.

Öztürk, A. (2019). Siyaseti Düşünmek, İstanbul: Doruk Yayınları.

Sarıbay, A.Y. (1998). Siyaset, Demokrasi ve Kimlik, Bursa: Asa Kitabevi.

Schmitt, C. (2018). Siyasal Kavramı, ( Göztepe, E. Çev.), İsanbul: Metis Yayınları.

Sennett, R. (2016). Karakter Aşınması, (Yıldırım, B. Çev.), İstanbul: Ayrıntı Yayınları. 
Standing, G. (2019). Prekarya, (Bulut,E. Çev.), İstanbul: İletişim Yayınları.

Taggart, P. (2004). Popülizm, (Yıldırım, B. Çev.), İstanbul: İstanbul Bilgi Üniversitesi Yayınları.

Tokdoğan, N. (2018). Yeni Osmanlıcllı, İstanbul: İletişim Yayınları.

Tosun, T. \& Tosun G.E. (2019), “31 Mart'tan 23 Haziran'a Türkiye ve İstanbul'da Yerel Seçimler”, Özgürlük Araştırmalarl, Sayı:11.

Tukel Paker, İ. B. (2017) Yeni Muhafazakâr Gençlik Kültürü, (Yayımlanmamış Doktora Tezi), İzmir: Ege Üniversitesi.

Uzgel, İ. (2010). “AKP: Neoliberal Dönüşümün Yeni Aktörü”, AKP Kitabl, Uzgel, İ..\& Duru, B. (Der.), Ankara: Phoneix Yayınları.

Yaraşır,V. \& Aygün T. (2002). Siyasal İslam ve AKP, İstanbul: Akyüz Yayın Grubu.

Yavuz, M. H. (2010). AK Parti: Toplumsal Değişsimin Yeni Aktörleri, Yavuz, M. H. (Ed.), İstanbul: Kitap Yayınevi.

Yavuz, M. H. (2011). Laiklik, Demokrasi, Kürt Sorunu ve İslam, (Adal1, L. Çev.), İstanbul: Kitap Yayınevi.

Yavuz, M. H. (2005). Modernleşen Müslümanlar, (Yıldız. A. Çev.), İstanbul: Kitap Yayınevi.

Yılmaz, C. (2013). "Orta Sınıfların Üzerine Düşünmek: İstanbul'da Orta Sınıfların Ajandasına Risk Yazmak", İstanbul: Müstesna Şehrin İstisna Hali, Çavdar, A. \& Tan, P. (Der.), İstanbul: Sel Yayınları.

\section{İnternet Kaynakça}

https://www.bbc.com/turkce/haberler-dunya-49416431. İstanbul'daki Suriyeliler - Financial Times: Türk hükümeti kayıt dışı göçmenlere yönelik kısıtlamaları artırdı. Erişim Tarihi: 04.04.2020

http://www.cumhuriyet.com.tr/haber/kpss-birinciligi-atanmasina-yetmedi-1723600.KPSS birinciliği atanmasına yetmedi. Erişim Tarihi: 15.03.2020.

https://www.haberler.com/kpss-turkiye-birincisi-mulakatta-elendi-11730185-haberi/KPSS Türkiye Birincisi, Mülakatta Elendi. Erişim Tarihi: 15.03.2020.

Yüksel Taşkın, "31 Mart-23 Haziran Seçimleri Türkiye Sağı Açısından Ne Anlama Geliyor?”, https://www.birikimdergisi.com/haftalik/9605/31-mart-23-haziran-secimleri-turkiye-sagiacisindan-ne-anlama-geliyor\#.XeaP5-gzbIU. Erişim Tarihi: 07.02.2020. 
Metropolitan Turbulence: Local Elections and the Sociological Dynamics on the Background of the Conservative Political Policy

Journal of Urban Academy | Volume: 13 Issue: 2 | ISSN: 2146-9229 